\title{
Protective roles of intra-arterial mild hypothermia and arterial thrombolysis in acute cerebral infarction
}

\author{
Xiaoxiang Peng ${ }^{1,2}$, Yue Wan², Wenjun Liư ${ }^{2}$, Bitang Dan², Li Lin² and Zhouping Tang ${ }^{1 *}$
}

\begin{abstract}
Objective: Herein, we evaluated the efficacy and safety of intra-arterial mild hypothermia in combination with arterial thrombolysis to treat acute cerebral infarction due to middle cerebral artery occlusion.

Methods: A total of 26 patients with acute middle cerebral artery occlusion were divided into a normothermia group $(n=15)$ and a mild hypothermia group $(n=11)$. The infarct volumes at $24 \mathrm{~h}$ and 7 days after the operation were compared between the normothermia group and the mild hypothermia group. Additionally, we compared neurological deficit scores between the two groups at $24 \mathrm{~h}, 7$ days, and 1 mo after the operation.

Results: The infarct volumes and neurological deficit scores of the mild hypothermia group were significantly reduced compared to those in the normothermia group $(p<0.05)$. Furthermore, no adverse reactions or complications occurred in the mild hypothermia group.

Conclusion: Intra-arterial mild hypothermia reduced infarct volume after ischemia-reperfusion injury in the arterial thrombolysis of an acute cerebral infarction. Additionally, it improved the prognosis of patients with an acute middle cerebral artery occlusion, suggesting that this procedure is safe and effective for treating acute cerebral infarction.
\end{abstract}

Keywords: Mild hypothermia, Acute cerebral infarction, Arterial thrombolysis, Cerebral protection

\section{Background}

Ischemic cerebrovascular disease, which is otherwise known as a stroke, is the second leading global cause of mortality after coronary heart disease and a major cause of neurological disability (Lopez et al. 2006). Approximately 17 million strokes occur worldwide each year (Feigin et al. 2014), and stroke is not only a life-threatening disease, but also a recurrent disease (Birns and Bhalla 2015). Following the acute phase, stroke patients often require long-term rehabilitation and nursing home care with ongoing support from their community (Mikulik and Wahlgren 2015). Thus, stroke is a devastating disease and a major economic burden on society (Mounica 2015). Moreover, the quality of life of stroke patients generally remains poor (van Eeden et al. 2015).

\footnotetext{
*Correspondence: zhoupingtang@126.com

1 Department of Neurology, Tongji Medical College, Huazhong University of Science and Technology, Wuhan 430074, China

Full list of author information is available at the end of the article
}

Ischemic cerebrovascular disease that involves an acute middle cerebral artery occlusion is associated with higher rates of disability and mortality (Gawlitza et al. 2016). Typically, for such a condition, early stage intravenous thrombolysis is performed (The National Institute of Neurological Disorders and Stroke rt-PA Stroke Study Group 1995) and the drug alteplase, a tissue plasminogen activator, is administered (Campbell et al. 2015a). This is the only therapy with a proven efficacy for acute ischemic stroke when used within 3-5 h after stroke onset (Fisher and Saver 2015). However, because of the complexity of intravenous thrombolysis (Shao et al. 2015), little improvement has been made in the use of thrombolysis procedures for acute stroke (Marshall 2015).

The multicenter randomized clinical trial of endovascular treatment for acute ischemic stroke in the Netherlands (MR CLEAN) reported on the efficacy of intra-arterial (IA) treatment for acute ischemic stroke (AIS) (Rozeman et al. 2016). Their results indicated that IA therapy 
is beneficial for patients with an acute middle cerebral artery occlusion. Arterial thrombolysis can promptly restore blood supply to ischemic brain tissue and protect the brain tissue within the penumbra. However, arterial thrombolysis can also trigger ischemic-reperfusion injury; therefore, intra-arterial thrombolysis must be carried out within a strict time frame. Ischemia-reperfusion injury is a major cause of post-stroke impairment, which seriously affects the quality of life and the functional rehabilitation of stroke patients (Liu et al. 2015).

Induced hypothermia has been used to prevent or reduce ischemia-reperfusion injury. For example, it has been shown that a combination of mild hypothermia and sodium hydrosulfide treatment is beneficial for reducing hippocampal apoptosis and pathology (Dai et al. 2016). In another study, deep hypothermia and diazoxide, a potassium channel activator, were correlated with a reduction in DNA fragmentation and the inhibition of mitochondrial cytochrome $c$ release and caspase- 3 activation (He et al. 2008). Further, there have been 5 randomized controlled trials (RCTs) showing the benefit of intra-arterial endovascular treatment for acute ischemic stroke (MR CLEAN, REVASCAT, ESCAPE, SWIFT PRIME, EXTEND-IA) (Berkhemer et al. 2015; Campbell et al. 2015b; Goyal et al. 2015; Jovin et al. 2015; Saver et al. 2015).

Most stroke patients are referred to specialists too late for optimal arterial thrombolysis. Thus, we here evaluated the utility of intra-arterial mild hypothermia combined with arterial thrombolysis for treating acute middle cerebral artery occlusion.

\section{Methods}

\section{Subjects}

We selected patients based on five criteria. First, patients clinically diagnosed with an acute middle cerebral artery occlusion and disease onset of less than $6 \mathrm{~h}$ were included. Second, patients with early signs of cerebral hemorrhage and cerebral infarction shown on a cranial computed tomography (CT) scan were excluded. Third, we restricted the age of the patients to between 18 and 75 years, inclusive. Fourth, only patients without severe organ dysfunction or a bleeding tendency were included. Finally, we required that the etiology of the cerebral infarct of the patients was atherosclerosis. Patients with a disease onset duration of more than $6 \mathrm{~h}$ were excluded from surgery of the vascular occlusion. This study was conducted in accordance with the declaration of Helsinki. This study was conducted with approval from the Ethics Committee of Huazhong University of Science and Technology. Written informed consent was obtained from all participants. The protocol number of the study was QJX2010-43.

\section{Grouping}

A total of 26 patients with an acute middle cerebral artery occlusion were randomly divided into a normothermia group $(\mathrm{n}=15)$ and a mild hypothermia group $(\mathrm{n}=11)$. All 26 patients with acute MCA (16 males, 10 females). Patients in the mild hypothermia group received arterial thrombolysis combined with intra-arterial mild hypothermia. To induce neuroprotection, we used a partial mild hypothermia temperature range of $28-33{ }^{\circ} \mathrm{C}$. The patients in the conventional treatment group had met the inclusion criteria but were either unsuitable for interventional therapy, or their legal guardian rejected the therapy.

\section{Operation}

The vascular occlusion site in each patient was confirmed using conventional cerebral angiography under anesthesia. Using a digital subtraction angiography system, we inserted the microguidewire (PT Graphix ${ }^{\mathrm{TM}}$, Boston Scientific, Marlborough, MA, USA) with a microcatheter (Rebar ${ }^{\mathrm{TM}}-18$, ev3, Plymouth, MN, USA) through the thrombus. Then, the microguidewire was pulled out and the angiography was performed through the inserted microcatheter. After confirmation that the distal vascular was removed, Ringer's solution $(50 \mathrm{~mL} / \mathrm{min}$, total $500 \mathrm{~mL}$ ) at $4{ }^{\circ} \mathrm{C}$ was pumped into the brain tissue through the microcatheter over $10 \mathrm{~min}$ so that the temperature of the local brain tissue was quickly reduced to induce mild hypothermia. The Ringer's solution consisted of $120 \mathrm{mM}$

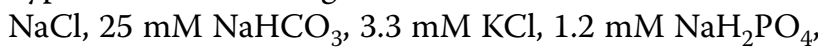
$1.8 \mathrm{mM} \mathrm{CaCl}_{2}, 2.4 \mathrm{mM} \mathrm{MgSO}_{4}$, and $10 \mathrm{mM}$ dextrose, and was percolated with $95 \% \mathrm{O}_{2}$ and $5 \% \mathrm{CO}_{2}$ before use. Subsequently, super-selective thrombolysis with urokinase was carried out through the inserted microcatheter in combination with balloon dilatation (Maverike ${ }^{\mathrm{TM}}$, Boston Scientific), stent embolectomy (Solitaire ${ }^{\mathrm{TM}}$ FR, ev3), or implantation of the stent into a blood vessel to restore blood flow.

\section{Neurological deficit scoring}

Neurological deficit scoring according to the National Institutes of Health Stroke Scale scoring method was performed at $24 \mathrm{~h}, 7$ days, and $1 \mathrm{mo}$ after the operation.

\section{Determination of infarct volume}

The infarct sizes of each patient were determined at $24 \mathrm{~h}$ and 7 days after the operation using cranial magnetic resonance imaging (MRI) (Philips, Eindhoven, Netherlands) and diffusion weighted imaging. A 3.0 Tesla MRI scan was performed using a susceptibility weighted protocol that was optimized for brain imaging. The infarct volumes were calculated using the Streiner formula. 


\section{Determination of clinical indexes}

The blood pressure, heart rate, blood glucose, blood gas, and coagulation condition of each patient were recorded $24 \mathrm{~h}$ after the operation.

\section{Statistical analysis}

SPSS statistical software (version 11.5; IBM Corporation, Armonk, NY, USA) was used to analyze the data. Measurement data are reported here as the mean \pm standard deviation (SD) and groups were compared using a $t$ test. Numeration data were compared using a Chi squared test. For all of the results, p values less than 0.05 were considered statistically significant.

\section{Results}

\section{Infarct volumes after induced intra-arterial mild} hypothermia

The representative MRIs were presented in the normothermia group and mild hypothermia group (Fig. 1). The average pre-treatment infarct volumes in the normothermia and mild hypothermia groups were $25.03 \pm 10.12$ and $24.91 \pm 9.35 \mathrm{~mm}^{3}$, respectively. The average infarct volume in the mild hypothermia group was $13.45 \pm 6.01 \mathrm{~mm}^{3}$ $24 \mathrm{~h}$ after the operation and $12.25 \pm 7.42 \mathrm{~mm}^{3} 7$ days after the operation. The average infarct volume in the mild hypothermia group was significantly smaller than that in the normothermia group at both $24 \mathrm{~h}$ and 7 days after the operation $(p<0.05$; Table 1$)$.

\section{Neurological scores after intra-arterial mild hypothermia}

The neurological deficit scores were $16.75 \pm 8.24$ and $16.25 \pm 8.51$ in the normothermia group and mild hypothermia group, respectively. The mean neurological deficit scores for the mild hypothermia group were $10.04 \pm 6.85$ at $24 \mathrm{~h}, 9.06 \pm 6.20$ at 7 days, and $7.06 \pm 5.13$ at $1 \mathrm{mo}$. The neurological scores in the mild hypothermia group prominently improved at $24 \mathrm{~h}$, 7 days, and 1 mo after the operation compared with those scores in the normothermia group $(p<0.05$; Table 2$)$.

\section{Clinical characteristics of the patients after both treatments}

The blood pressure, heart rate, blood glucose, blood gas, and coagulation conditions of the patients in the two groups were recorded at $24 \mathrm{~h}$ after the operation and compared. No significant changes in these clinical characteristics were observed between the two groups $(p>0.05$; Table 3$)$. There was no significant difference regarding complications between the two groups. Included in this analysis were embolization into new territories outside the target downstream territory of the occluded vessel in 2 of the 26 patients $(7.7 \%)$ and procedure-related vessel dissections in 1 patient (3.8\%).

\section{Discussion}

Middle cerebral artery occlusion generally leads to a massive cerebral infarction, which has a poor prognosis that includes severe disability and death. Thus, timely recovery of blood flow into the infarct area is critical for these patients. The recanalization rate for intravenous thrombolysis of a middle cerebral artery occlusion is low; thus, intra-arterial thrombolysis has been increasingly applied in clinical practice to greatly improve the recanalization rate. A retrospective study of 350 patients with acute stroke undergoing a variety of endovascular treatment techniques found that angioplasty combined with intraarterial thrombolysis can greatly improve the recanalization rate (Brekenfeld et al. 2005). Among our 22 patients undergoing thrombolysis and angioplasty, 19 patients were completely recanalized and only 3 patients were partially recanalized. The high recanalization rate in our study is likely due to our intra-vascular technique and strict patient inclusion criteria.

Since the first use of mild hypothermia induction for clinical treatment by the American neurosurgeon Fay in 1938, clinical studies of mild hypothermia have been successively reported. Since the 1980s, several studies on the application of mild hypothermia for cerebral ischemia have been carried out (Baker et al. 1991; Ridenour et al. 1992; Zausinger et al. 2000). These studies have shown that the induction of mild hypothermia between 28 and $33{ }^{\circ} \mathrm{C}$ has neuroprotective effects. In the clinic, ice blankets, ice caps, and alcohol sponge baths are often used to reduce body temperature. At the International Stroke Conference in 2010, a preliminary report of a clinical trial using endovascular hypothermia combined with intravenous thrombolysis for the treatment of acute ischemic stroke showed that mild hypothermia treatment is safe and feasible (Hemmen et al. 2010). Another study used mild hypothermia combined with interventional arterial thrombolysis for the treatment of acute ischemic stroke and achieved the desired cerebral protective effects (Ding et al. 2002). Subsequently, numerous studies have confirmed that mild hypothermia after stroke can protect brain structure and function at the cellular level (De Georgia et al. 2004; Hemmen and Lyden 2007; Krieger et al. 2001; Zausinger et al. 2003; Zhang et al. 2009). One meta-analysis of 101 animal experiments showed that mild hypothermia can simultaneously reduce infarct volume by $44 \%$ on average and increase neurobehavioral scores by $46 \%$ (van der Worp et al. 2007). Subsequent experiments demonstrated that localized mild hypothermia combined with intra-arteriovenous thrombolysis is highly effective (Chen et al. 2013; Choi et al. 2010; Guluma et al. 2006; Hong et al. 2014; Konstas et al. 2007; Piironen et al. 2014; Zhao et al. 2009). Here, we found that the average 

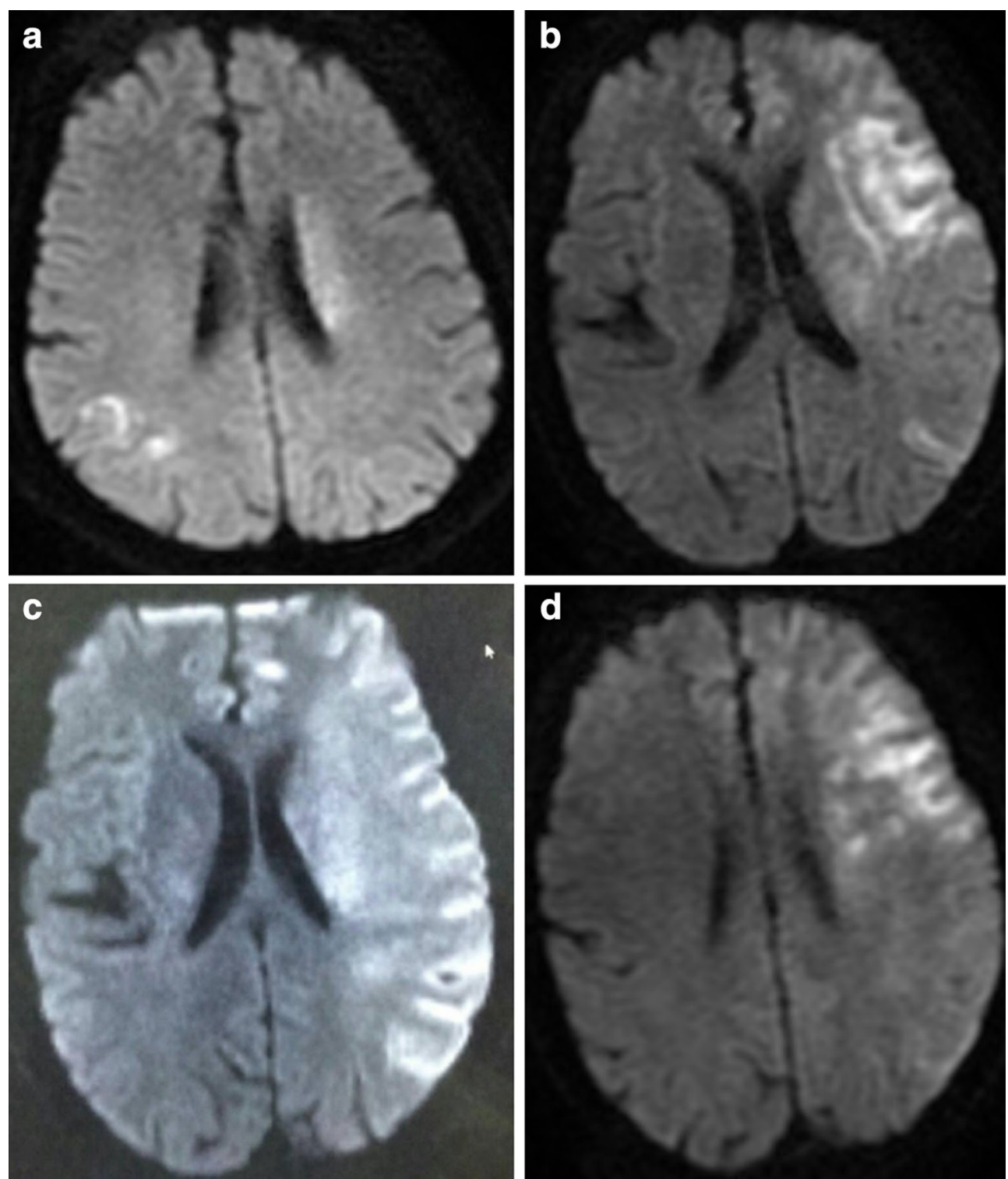

Fig. 1 The representative MRIs were presented in the normothermia group and mild hypothermia group. a The representative MRI of preoperative in the normothermia group. $\mathbf{b}$ The representative MRI of postoperation 1 week in the normothermia group. $\mathbf{c}$ The representative MRI of preoperative in the mild hypothermia group. $\mathbf{d}$ The representative MRI of postoperation 1 week in the mild hypothermia group

Table 1 The infarct volumes $\left(\mathrm{mm}^{3}\right)$ in the two groups at different time points (mean \pm SD)

\begin{tabular}{|c|c|c|c|}
\hline \multirow[t]{2}{*}{ Groups } & \multirow{2}{*}{$\begin{array}{l}\text { The infarct volumes } \\
\text { in pre-treatment } \\
\text { o h }\end{array}$} & \multicolumn{2}{|c|}{$\begin{array}{l}\text { The infarct volumes } \\
\text { after the operation time }\end{array}$} \\
\hline & & $24 \mathrm{~h}$ & 7 days \\
\hline Normothermia & $25.03 \pm 10.12$ & $25.56 \pm 10.22$ & $26.26 \pm 10.86$ \\
\hline Mild hypothermia & $24.91 \pm 9.35$ & $13.45 \pm 6.01^{*}$ & $12.25 \pm 7.42^{*}$ \\
\hline
\end{tabular}

* $P<0.05$ versus the normothermia group 
Table 2 The neurological scores in the two groups at different time points (NIHSS)

\begin{tabular}{|c|c|c|c|}
\hline \multirow[t]{2}{*}{ Groups } & \multicolumn{3}{|c|}{$\begin{array}{l}\text { The neurological scores after the operation } \\
\text { time }\end{array}$} \\
\hline & $24 \mathrm{~h}$ & 7 days & $1 \mathrm{~m}$ \\
\hline Normothermia & $12.26 \pm 5.53$ & $11.65 \pm 5.87$ & $9.21 \pm 3.43$ \\
\hline Mild hypothermia & $10.04 \pm 6.85^{*}$ & $9.06 \pm 6.20^{*}$ & $7.06 \pm 5.13^{*}$ \\
\hline
\end{tabular}

* $P<0.05$ versus the normothermia group

Table 3 The clinical characteristics of the patients in the two groups at $24 \mathrm{~h}$ after the operation

\begin{tabular}{lllll}
\hline Groups & $\begin{array}{l}\text { Blood pressure } \\
(\mathbf{m m H g})\end{array}$ & $\begin{array}{l}\text { Heart rate } \\
\text { (times/min) }\end{array}$ & $\begin{array}{l}\text { Blood glucose } \\
\text { (concentration, } \\
\text { mmol/l) }\end{array}$ & $\begin{array}{l}\text { Blood gas } \\
(\mathbf{m m H})\end{array}$ \\
\hline Normothermia & $132 \pm 6.27 / 72 \pm 5.15$ & $75 \pm 5.06$ & $6.17 \pm 2.48$ & $92.4 \pm 5.12$ \\
$\begin{array}{l}\text { Mild } \\
\text { hypothermia }\end{array}$ & $138 \pm 9.27 / 80 \pm 8.35$ & $82 \pm 7.80$ & $7.82 \pm 2.73$ & $93.1 \pm 5.89$ \\
\hline
\end{tabular}

$P>0.05$ versus the normothermia group

infarct volume decreased from 25 to $13 \mathrm{~cm}^{3}$ in the first $24 \mathrm{~h}$ for the hypothermia group, which was nearly a $50 \%$ volume reduction. Several experimental studies have confirmed that the therapeutic effects of mild hypothermia occur through blocking of reperfusion injury. In the early stage of a cerebral infarction, mild hypothermia therapy can reduce brain tissue injury in the ischemic penumbra and improve cerebrovascular autoregulation, thereby reducing neuronal cell death. In addition, mild hypothermia can protect the blood-brain barrier, reduce cerebral edema, and decrease the influx of calcium to block its neurotoxic effects (Krieger and Yenari 2004; Rogalewski et al. 2006). In addition to the significant infarct volume reduction, average NIHSS scores at various time points were roughly 2 points lower in the hypothermia group. There was a statistically significant difference between the 2 groups. The clinical symptoms improved have three time points, and infarct volume has three time points. The average NIHSS scores for the hypothermia group at $24 \mathrm{~h}$ and 7 days after surgery were lower than the average pre-operation score. Although the NIHSS scores were very close at 7 days post-operation, we confirmed that the scores were true and accurately measured. The present study used a small sample size; therefore, the results could not be further analyzed by stratification of the ischemia and reperfusion duration after mild hypothermia and thrombolysis treatment. Thus, future studies should continue to investigate the therapeutic efficacy of mild hypothermia combined with intra-arteriovenous thrombolysis after cerebral infarction.
Authors' contributions

ZT conception and design and critical revision of the manuscript. XP, YW and WL Data collection. BD, LL and ZT Analysis and interpretation. XP Writing the manuscript. All authors read and approved the final manuscript.

\section{Author details}

${ }^{1}$ Department of Neurology, Tongji Medical College, Huazhong University of Science and Technology, Wuhan 430074, China. ${ }^{2}$ Department of Neurology, Wuhan Third Hospital, Wuhan 430074, China.

\section{Acknowledgements}

We gratefully acknowledge the support and contributions of the participants and field workers. This work was supported by QJX2010-43.

\section{Competing interests}

The authors declare that they have no competing interests.

Received: 26 April 2016 Accepted: 4 November 2016

Published online: 17 November 2016

\section{References}

Baker CJ, Onesti ST, Barth KN, Prestigiacomo CJ, Solomon RA (1991) Hypothermic protection following middle cerebral artery occlusion in the rat. Surg Neurol 36:175-180

Berkhemer OA, Fransen PS, Beumer D, van den Berg LA, Lingsma HF, Yoo AJ, Schonewille WJ, Vos JA, Nederkoorn PJ, Wermer MJ, van Walderveen MA, Staals J, Hofmeijer J, van Oostayen JA, Lycklama A, Nijeholt GJ, Boiten J, Brouwer PA, Emmer BJ, de Bruijn SF, van Dijk LC, Kappelle LJ, Lo RH, van Dijk EJ, de Vries J, de Kort PL, van Rooij WJ, van den Berg JS, van Hasselt BA, Aerden LA, Dallinga RJ, Visser MC, Bot JC, Vroomen PC, Eshghi O, Schreuder TH, Heijboer RJ, Keizer K, Tielbeek AV, den Hertog HM, Gerrits DG, van den Berg-Vos RM, Karas GB, Steyerberg EW, Flach HZ, Marquering HA, Sprengers ME, Jenniskens SF, Beenen LF, van den Berg R, Koudstaal PJ, van Zwam WH, Roos YB, van der Lugt $A$, van Oostenbrugge RJ, Majoie CB, Dippel DW (2015) A randomized trial of intraarterial treatment for acute ischemic stroke. N Engl J Med 372:11-20

Birns J, Bhalla A (2015) Secondary prevention of stroke. Br J Hosp Med (Lond) 76:C104-C107

Brekenfeld C, Remonda L, Nedeltchev K, v. Bredow F, Ozdoba C, Wiest R, Arnold M, Mattle HP, Schroth G (2005) Endovascul Arneu roradiological treatment of acute ischemic stroke: techniques and results in 350 patients. Neurol Res 27:29-35

Campbell BC, Meretoja A, Donnan GA, Davis SM (2015a) Twenty-year history of the evolution of stroke thrombolysis with intravenous alteplase to reduce long-term disability. Stroke 46:2341-2346

Campbell BC, Mitchell PJ, Kleinig TJ, Dewey HM, Churilov L, Yassi N, Yan B, Dowling RJ, Parsons MW, Oxley TJ, Wu TY, Brooks M, Simpson MA, Miteff F, Levi CR, Krause M, Harrington TJ, Faulder KC, Steinfort BS, Priglinger M, Ang T, Scroop R, Barber PA, McGuinness B, Wijeratne T, Phan TG, Chong W, Chandra RV, Bladin CF, Badve M, Rice H, de Villiers L, Ma H, Desmond PM, Donnan GA, Davis SM (2015b) Endovascular therapy for ischemic stroke with perfusion-imaging selection. N Engl J Med 372:1009-1018

Chen J, Fredrickson V, Ding Y, Cheng H, Wang N, Ling F, Ji X (2013) Enhanced neuroprotection by local intra-arterial infusion of human albumin solution and local hypothermia. Stroke 44:260-262

Choi JH, Marshall RS, Neimark MA, Konstas AA, Lin E, Chiang YT, Mast H, Rundek T, Mohr JP, Pile-Spellman J (2010) Selective brain cooling with endovascular intracarotid infusion of cold saline: a pilot feasibility study. AJNR Am J Neuroradiol 31:928-934

Dai HB, Xu MM, Lv J, Ji XJ, Zhu SH, Ma RM, Miao XL, Duan ML (2016) Mild hypothermia combined with hydrogen sulfide treatment during resuscitation reduces hippocampal neuron apoptosis via NR2A, NR2B, and PI3K-Akt signaling in a rat model of cerebral ischemia-reperfusion injury. Mol Neurobiol 53:4865-4873

De Georgia MA, Krieger DW, Abou-Chebl A, Devlin TG, Jauss M, Davis SM, Koroshetz WJ, Rordorf G, Warach S (2004) Cooling for acute ischemic brain damage (COOL AID): a feasibility trial of endovascular cooling. Neurology 63:312-317 
Ding Y, Li J, Rafols JA, Phillis JW, Diaz FG (2002) Prereperfusion saline infusion into ischemic territory reduces inflammatory injury after transient middle cerebral artery occlusion in rats. Stroke 33:2492-2498

Feigin VL, Forouzanfar MH, Krishnamurthi R, Mensah GA, Connor M, Bennett DA, Moran AE, Sacco RL, Anderson L, Truelsen T, O'Donnell M, Venketasubramanian N, Barker-Collo S, Lawes CM, Wang W, Shinohara Y, Witt E, Ezzati M, Naghavi M, Murray C (2014) Global and regional burden of stroke during 1990-2010: findings from the Global Burden of Disease Study 2010. Lancet 383:245-254

Fisher M, Saver JL (2015) Future directions of acute ischaemic stroke therapy. Lancet Neurol 14:758-767

Gawlitza M, Friedrich B, Hobohm C, Schaudinn A, Schob S, Quäschling U, Hoffmann KT, Lobsien D (2016) Distance to thrombus in acute middle cerebral artery occlusion predicts target mismatch and ischemic penumbra. J Stroke Cerebrovasc Dis 25:298-305

Goyal M, Demchuk AM, Menon BK, Eesa M, Rempel JL, Thornton J, Roy D, Jovin TG, Willinsky RA, Sapkota BL, Dowlatshahi D, Frei DF, Kamal NR, Montanera WJ, Poppe AY, Ryckborst KJ, Silver FL, Shuaib A, Tampieri D, Williams D, Bang OY, Baxter BW, Burns PA, Choe H, Heo JH, Holmstedt CA, Jankowitz B, Kelly M, Linares G, Mandzia JL, Shankar J, Sohn SI, Swartz RH, Barber PA, Coutts SB, Smith EE, Morrish WF, Weill A, Subramaniam S, Mitha AP, Wong JH, Lowerison MW, Sajobi TT, Hill MD (2015) Randomized assessment of rapid endovascular treatment of ischemic stroke. N Engl J Med 372:1019-1030

Guluma KZ, Hemmen TM, Olsen SE, Rapp KS, Lyden PD (2006) A trial of therapeutic hypothermia via endovascular approach in awake patients with acute ischemic stroke: methodology. Acad Emerg Med 13:820-827

He X, Mo X, Gu H, Chen F, Gu Q, Peng W, Qi J, Shen L, Sun J, Zhang R, Kj Y (2008) Neuroprotective effect of diazoxide on brain injury induced by cerebral ischemia/reperfusion during deep hypothermia. J Neurol Sci 268:18-27

Hemmen TM, Lyden PD (2007) Induced hypothermia for acute stroke. Stroke 38:794-799

Hemmen TM, Raman R, Guluma KZ, Meyer BC, Gomes JA, Cruz-Flores S, Wijman CA, Rapp KS, Grotta JC, Lyden PD (2010) Intravenous thrombolysis plus hypothermia for acute treatment of ischemic stroke (IGTUS-L): final results. Stroke 41:2265-2270

Hong JM, Lee JS, Song HJ, Jeong HS, Choi HA, Lee K (2014) Therapeutic hypothermia after recanalization in patients with acute ischemic stroke. Stroke 45:134-140

Jovin TG, Chamorro A, Cobo E, de Miquel MA, Molina CA, Rovira A, San Roman L, Serena J, Abilleira S, Ribo M, Millan M, Urra X, Cardona P, Lopez-Cancio E, Tomasello A, Castano C, Blasco J, Aja L, Dorado L, Quesada H, Rubiera M, Hernandez-Perez M, Goyal M, Demchuk AM, von Kummer R, Gallofre M, Davalos A (2015) Thrombectomy within 8 hours after symptom onset in ischemic stroke. N Engl J Med 372:2296-2306

Konstas AA, Neimark MA, Laine AF, Pile-Spellman J (2007) A theoretical model of selective cooling using intracarotid cold saline infusion in the human brain. J Appl Physiol (1985) 102:1329-1340

Krieger DW, Yenari MA (2004) Therapeutic hypothermia for acute ischemic stroke: What do laboratory studies teach us? Stroke 35:1482-1489

Krieger DW, De Georgia MA, Abou-Chebl A, Andrefsky JC, Sila CA, Katzan IL, Mayberg MR, Furlan AJ (2001) Cooling for acute ischemic brain damage (COOL AID): an open pilot study of induced hypothermia in acute ischemic stroke. Stroke 32:1847-1854

Liu F, Jiang YJ, Zhao HJ, Yao LQ, Chen LD (2015) Electroacupuncture ameliorates cognitive impairment and regulates the expression of apoptosisrelated genes $\mathrm{BCl}-2$ and $\mathrm{Bax}$ in rats with cerebral ischaemia-reperfusion injury. Acupunct Med 33:478-484
Lopez AD, Mathers CD, Ezzati M, Jamison DT, Murray CJ (2006) Global and regional burden of disease and risk factors, 2001: systematic analysis of population health data. Lancet 367:1747-1757

Marshall RS (2015) Progress in intravenous thrombolytic therapy for acute stroke. JAMA Neurol 72:928-934

Mikulik R, Wahlgren N (2015) Treatment of acute stroke: an update. J Intern Med 278:145-165

Mounica B (2015) Estimating the economic burden of stroke in South India: a cost-of-illness study. Value Health 18:A387

Piironen K, Tiainen M, Mustanoja S, Kaukonen KM, Meretoja A, Tatlisumak T, Kaste M (2014) Mild hypothermia after intravenous thrombolysis in patients with acute stroke: a randomized controlled trial. Stroke 45:486-491

Ridenour TR, Warner DS, Todd MM, McAllister AC (1992) Mild hypothermia reduces infarct size resulting from temporary but not permanent focal ischemia in rats. Stroke 23:733-738

Rogalewski A, Schneider A, Ringelstein EB, Schäbitz WR (2006) Toward a multimodal neuroprotective treatment of stroke. Stroke 37:1129-1136

Rozeman AD, Wermer MJ, Vos JA, Nijeholt GJ, Beumer D, Berkhemer OA, Dippel DW, Algra A, Boiten J, Schonewille WJ (2016) Evolution of intra-arterial therapy for acute ischemic stroke in the Netherlands: MR CLEAN pretrial experience. J Stroke Cerebrovasc Dis 25:115-121

Saver JL, Goyal M, Bonafe A, Diener HC, Levy El, Pereira VM, Albers GW, Cognard C, Cohen DJ, Hacke W, Jansen O, Jovin TG, Mattle HP, Nogueira RG, Siddiqui AH, Yavagal DR, Baxter BW, Devlin TG, Lopes DK, Reddy VK, du Mesnil de Rochemont R, Singer OC, Jahan R (2015) Stent-retriever thrombectomy after intravenous t-PA vs. t-PA alone in stroke. N Engl J Med 372:2285-2295

Shao Q, Zhu L, Li T, Wang Z, Li L, Bai W, He Y (2015) Management of tandem internal carotid and middle cerebral arterial occlusions with endovascular multimodal reperfusion therapy. Int J Neurosci 17:1-15

The National Institute of Neurological Disorders and Stroke rt-PA Stroke Study Group (1995) Tissue plasminogen activator for acute ischemic stroke. N Engl J Med 333:1581-1587

van der Worp HB, Sena ES, Donnan GA, Howells DW, Macleod MR (2007) Hypothemia in animal models of acute ischaemic stroke: a systematic review and meta-analysis. Brain 130:3063-3074

van Eeden M, van Heugten C, van Mastrigt GA, van Mierlo M, Visser-Meily JM, Evers SM (2015) The burden of stroke in the Netherlands: estimating quality of life and costs for 1 year poststroke. BMJ Open 5:e008220

Zausinger S, Hungerhuber E, Baethmann A, Reulen H, Schmid-Elsaesser R (2000) Neurological impairment in rats after transient middle cerebral artery occlusion: a comparative study under various treatment paradigms. Brain Res 863:94-105

Zausinger S, Westermaier T, Plesnila N, Steiger HJ, Schmid-Elsaesser R (2003) Neuroprotection in transient focal cerebral ischemia by combination drug therapy and mild hypothermia: comparison with customary therapeutic regimen. Stroke 34:1526-1532

Zhang S, Liu XZ, Liu ZL, Wang YM, Hu QL, Ma TZ, Sun SZ (2009) Stem cells modified by brain-derived neurotrophic factor to promote stem cells differentiation into neurons and enhance neuromotor function after brain injury. Chin J Traumatol 12:195-199

Zhao WH, Ji XM, Ling F, Ding YC, Xing CH, Wu H, Guo M, Xuan Y, Guan B, Jiang LL (2009) Local mild hypothermia induced by intra-arterial cold saline infusion prolongs the time window of onset of reperfusion injury after transient focal ischemia in rats. Neurol Res 31:43-51 